*ak RMIS View/Frint Document Cover Sheet tow

This document was retrieved from the Documentation and Records Manaqement (DRM) ISEARCH System. It is intended for Information only and may not be the most recent or updated version. Contact a Document Service Center (see Hanford Info for locations) if you need additional retrieval information.

Accession \#: D196004701

Document \#: SD-SNF-SP-006

Title/Desc:

TRIBAL \& STAKEHOLDER COMMUNICATION \& PARTICIPATION STRATEGY FOR THE SNF PROJECT

Pages: 19 


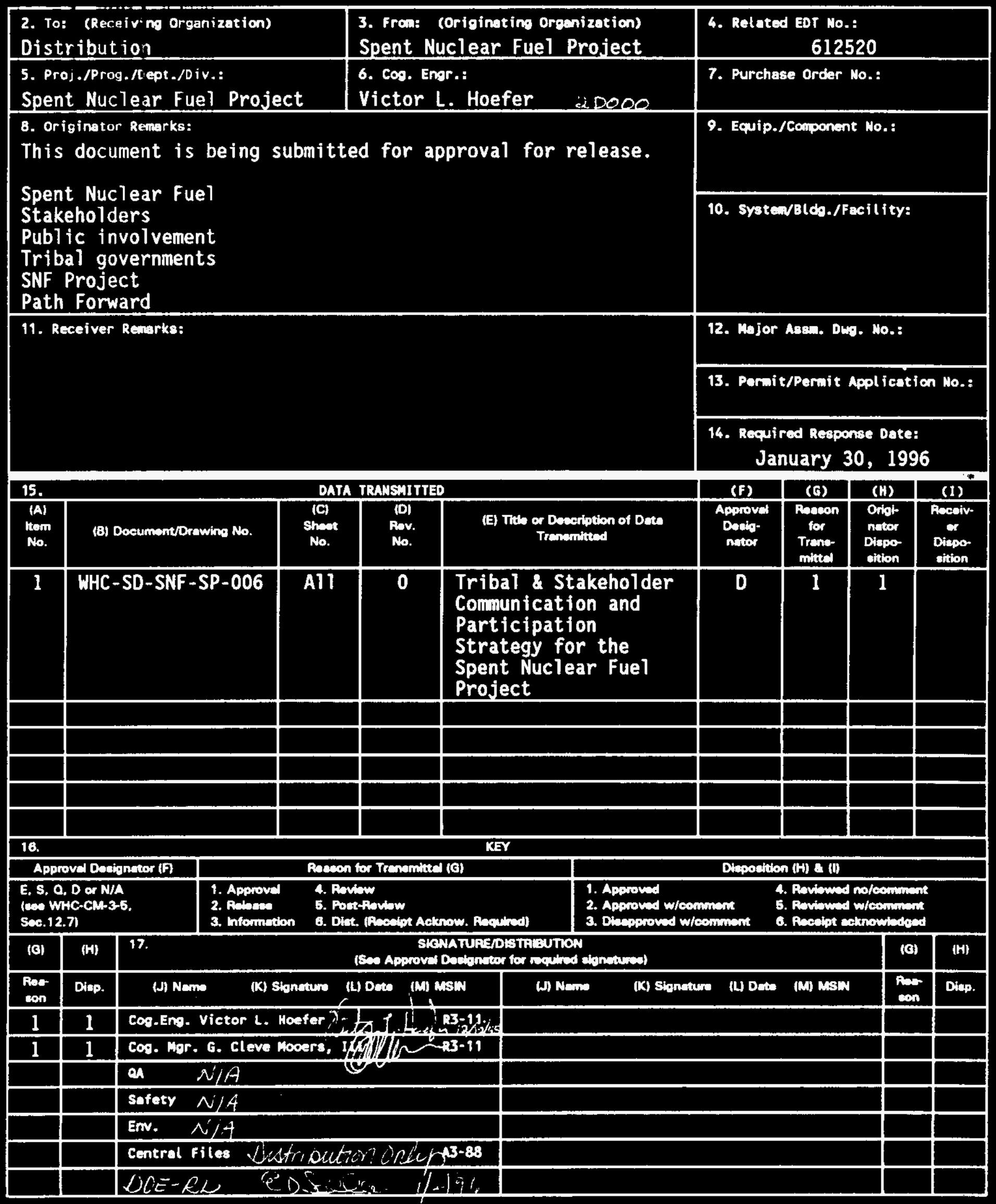


18.
Stionature of Hot
Originator

19.

Authorised Raprecentative Dato

for Recoiving Orgenization
20.

4.

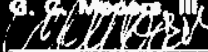

toonizatir Mencoer
21. DOE APPROVAL (if required) Ctrl. Mo.

[] Approved

d] Approved w/coumants

d] Disapproved w/comments

BD-7400-172-2 (04/94) GEF097 


\section{Tribal and Stakeholder Communication and Participation Strategy for the Spent Nuclear Fuel Project}

Victor 1. Hoefer

West inghouse Hanford Company, Richland, WA 99352

U.S. Department of Energy Contract DE-AC06-87RL10930

$\begin{array}{lll}\text { EDT/ECN: } 612520 & \text { UC: } 721 \\ \text { Org Code: } 20000 & \text { Charge Code: LA030 } \\ \text { B\&R Code: EW3135040 } & \text { Totai Pages: } 14 / 5\end{array}$

Key Words: Spent Nuclear Fuel, Stakeholders, Publ ic involvement, Tribal governments, SNF Project, Path Forward

Abstract: This document outlines a plan to ensure the effective involvement of the Hanford stakeholders and Tribal Governments in Spent Nuclear Fuel (SNF) Project issues and decisions. Stakeholders are defined as the public, news media, regulators, employees, Hanford Advisory Board and members of local, state and federal governments.

Experience here at Hanford has clearly shown that early and continued involvement of all interested parties in decision making is absolutely essential for fostering project success. Failure to recognize the importance of this interaction has resulted in significant cost in terns of time and money for several site programs.

TRADEMAK DISCLAImER. Reference herein to $\mathrm{cmy}$ spocific comarcial product, process, or service by trede news, tredemerk, manufacturer, or otherwise, does not necessarily constitute or imply its endorseasent, reccumendation, or fovoring by the united states covernment or eny agency thereof or its contrectors or subcontrectors.

Printed in the United States of Narice. To cbtain copies of this docuant, contact: uuC/BCs Document Control Services, P.0. Box 1970, Wilatep H6-08, Richlend un 99352, Phone (509) 372-2420; Fax (509) 376-4989.
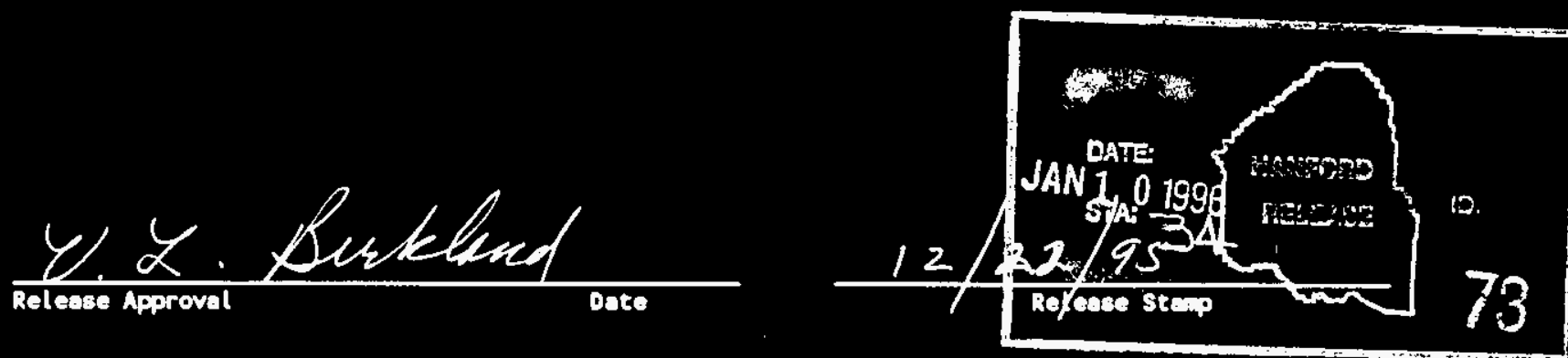

Approved for Public Release 


\section{SPENT NUCLEAR FUEL (SNF) PROJECT}

TRIBAL, STAKEHOLDER \& REGULATOR COMMUNICATION AND PARTICIPATION STRATEGY

Spent Nuclear Fuel Project

October 1995

Prepared for the U.S. Department of Energy

Office of Environmental Restoration and Waste Management

Westinghouse Hanford Company

P. O. Box 1970

Richland, Washington 99352 


\section{TABLE OF CONTENTS}

EXECUTIVE SUMMARY $\ldots \ldots \ldots \ldots \ldots \ldots \ldots \ldots \ldots \ldots$ ii

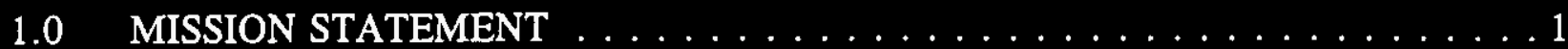

2.0 VISION STATEMENT $\ldots \ldots \ldots \ldots \ldots \ldots \ldots \ldots \ldots \ldots \ldots \ldots \ldots \ldots \ldots \ldots$

3.0 ELEMENTS OF THE PLAN

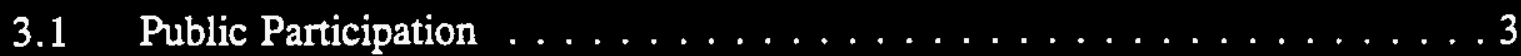

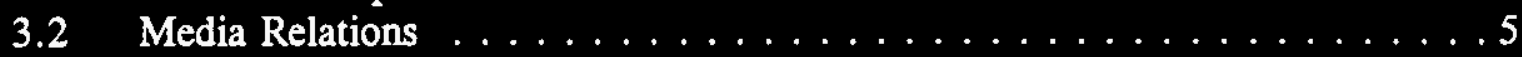

3.3 Governmental Relations $\ldots \ldots \ldots \ldots \ldots \ldots \ldots \ldots \ldots$

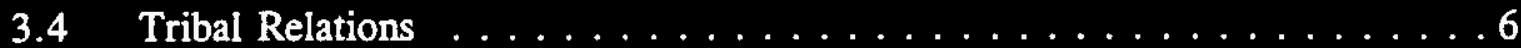

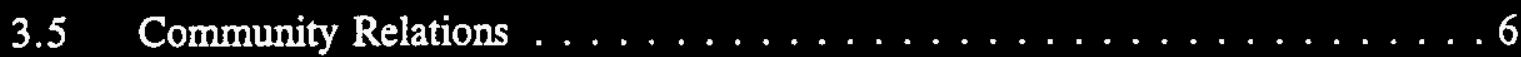

3.6 Employee Communications $\ldots \ldots \ldots \ldots \ldots \ldots \ldots \ldots$

4.0 COMMUNICATIONS ACTION PLAN $\ldots \ldots \ldots \ldots \ldots \ldots \ldots$ APPENDICES

A. Spent Nuclear Fuel Project Messages $\ldots \ldots \ldots \ldots \ldots \ldots \ldots \ldots$ A-1

B. Tribal Relations Messages $\ldots \ldots \ldots \ldots \ldots \ldots \ldots \ldots \ldots$ B-1

\section{FIGURES}

Figure 1: SNF Project Mission $\ldots \ldots \ldots \ldots \ldots \ldots \ldots \ldots \ldots \ldots \ldots \ldots$

Figure 2: Public Involvement Decision Process $\ldots \ldots \ldots \ldots \ldots \ldots$ 


\section{EXECUTIVE SUMMARY}

This document outlines a plan to ensure the effective involvement of the Hanford stakeholders, regulators and tribal governments in Spent Nuclear Fuel (SNF) Project issues and decisions. Stakeholders are defined as the public, news media, employees, and members of local, state, and federal governments.

Survey data and experience clearly shows that most people in the region still don't trust the Department of Energy (DOE) or its contractors to tell them the truth about past or present Hanford activities. This plan recognizes the prevalent "high risk, low trust" public perception and outlines a strategy to increase the credibility of DOE and Westinghouse Hanford Company (WHC).

Experience here at Hanford has clearly shown that early and continued involvement of all interested parties in decision making is absolutely essential for fostering project success. Failure to recognize the importance of this interaction has resulted in significant cost in terms of time and money for several Site programs.

The SNF Project intends to be proactive in the public involvement arena. Frequent, open, two-way communication with stakeholders, regulators, and tribal governments will be practiced and encouraged.

This plan contains mission and vision statements, as well as goals and objectives for public involvement, media relations, governmental, tribal and community relations, and employee communications. Appendices showing SNF Project and tribal relation messages are also included.

This plan will serve as a guide for SNF Project public involvement activities. 


\subsection{MISSION STATEMENT}

Support the successful completion of the SNF Project by maintaining timely and accurate, open two-way communications with our employees, the public, tribal governments, news media, and local, state, federal governments and regulators. (Figure 1)

\subsection{VISION STATEMENT}

Our goal is to build credibility with our customer, employees, the public, tribal governments, news media, and local, state, federal governments and regulators.

To build credibility, we must:

- be proactive, reliable, and always tell the truth.

- tell the whole truth, as soon as possible, in a simple way, to all the key audiences.

- recognize that Hanford is perceived by the stakeholders and tribal governments in a "high risk/low trust" environment.

- continue to talk about problems -- actual, potential, and perceived.

- we will never be given credit for solutions if we don't first talk about the problems.

- get our stakeholders, regulators and tribal governments meaningfully involved in major policy decisions before the decisions are made.

- provide accurate, timely information about imminent decisions to enable stakeholders, regulators and tribal governments to make informed judgements and offer valuable advice. 
Figure 1: SNF Project Mission

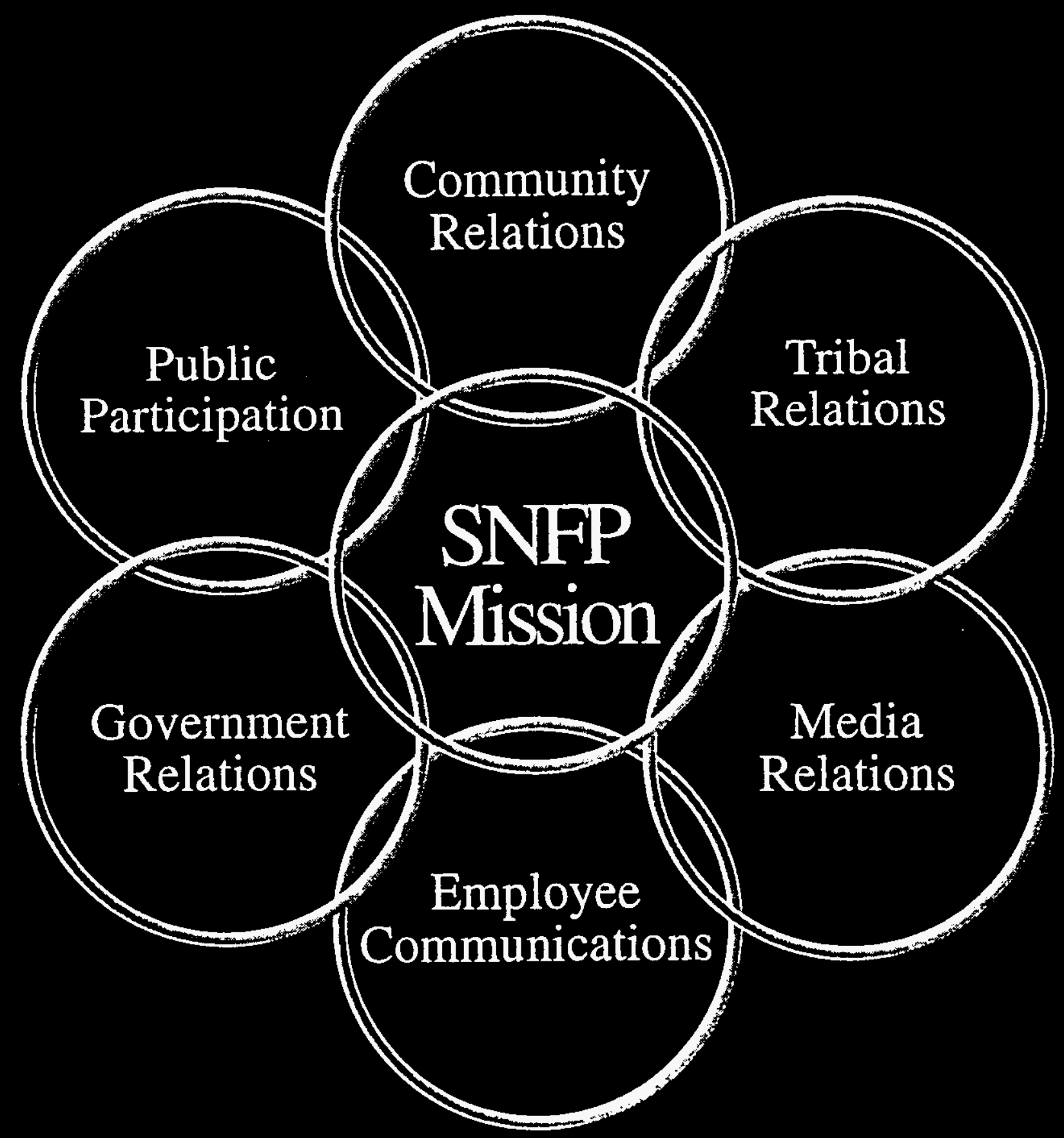




\subsection{ELEMENTS OF THE PLAN}

\subsection{PUBLIC INVOLVEMENT}

Goal:

Bring stakeholders perspectives and values to the SNF Project decision process. (Figure 2)

Objectives:

Involve the stakeholders, regulators and tribal governments early in the SNF Project decision-making process and factor resulting values and concerns into decisions.

Recognize that the success of our communication efforts with DOE, Congress and the news media are influenced largely by the effectiveness of our public involvement program.

Develop an inventory of future SNF Project decisions and a timeline which dictates our public involvement schedule of activities.

Supply stakeholders, regulators and tribal governments with timely and accurate information, written in non-technical terms, to enable them to make informed judgments. Examples are:

- SNF Project overview

- History of K Basin storage of spent N Reactor fuel

- Sludge and fuel characterization and handling

- Path Forward Recommendation

- Regulatory issues

- Wet and dry storage options

- Seismic vulnerability 


\section{Public Involvement Decision Process}

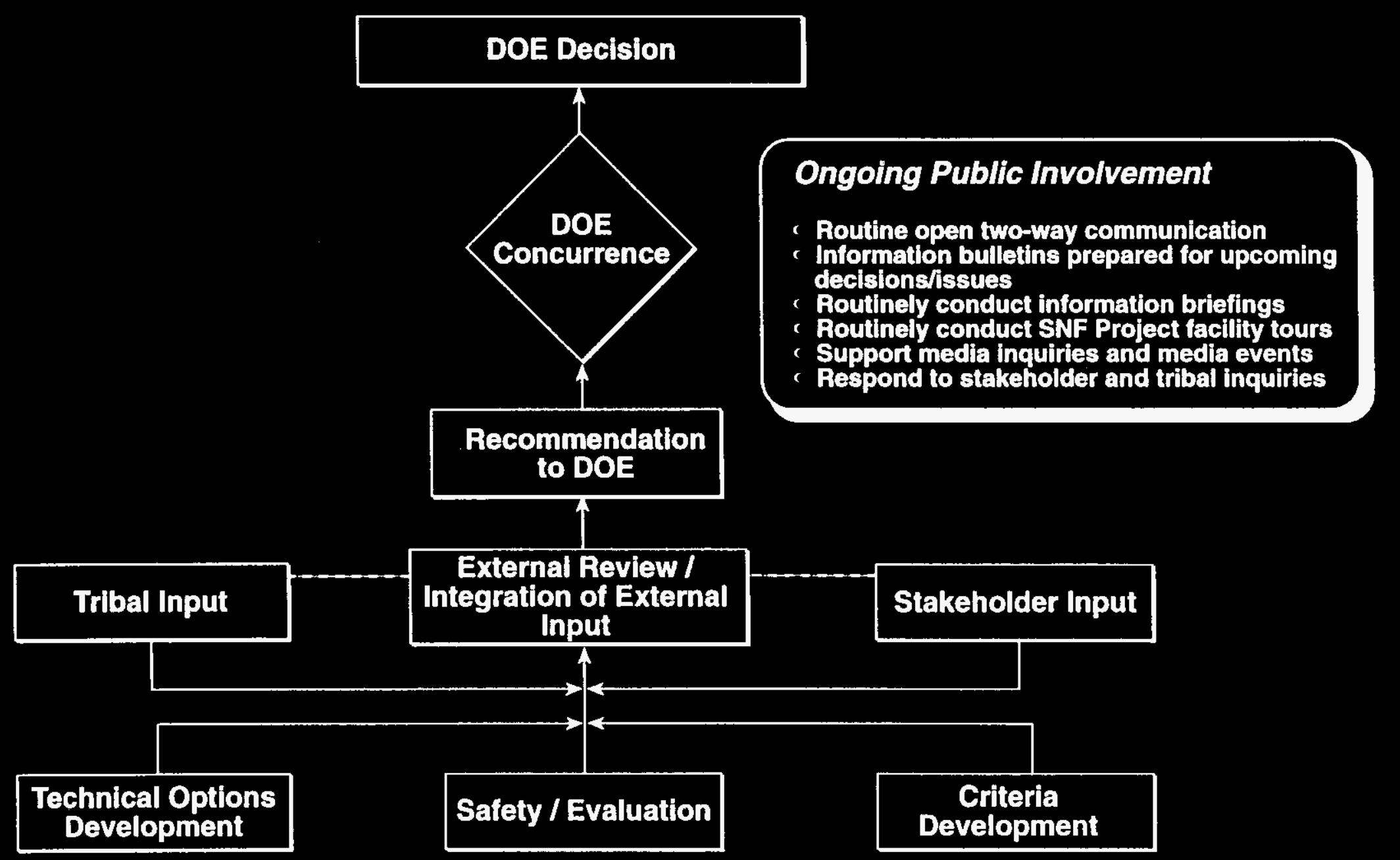




\subsection{MEDIA RELATIONS}

Goal:

Foster the flow of timely, accurate, and reliable information to the news media to help stakeholders, regulators and tribal governments become informed on project issues.

Objectives:

Build relationships with the local and regional news media.

- don't wait until issues hit the front page.

Strive for accurate and objective news coverage by continuing a media outreach program to develop relationships based on honesty, openness, and trust with major Northwest news outlets in Seattle, Spokane, and Portland.

Continue news briefings as appropriate for the local and regional media with appropriate DOE and WHC management.

Provide stories to the national trade press to ensure that progress made in the SNF Project receives appropriate recognition.

\subsection{GOVERNMENTAL RELATIONS}

Goal: officials.

Build and maintain the confidence of local, state, and federal government Objectives:

Communicate responsible stewardship of public funds and SNF Project progress.

Arrange Hanford Site tours for local, state, and federal elected officials and staff.

Ensure local, state, and federal elected officials and staff are kept current on SNF Project issues and developments. candidates.

Arrange Hanford Site summer tours and project briefings for legislative 


\subsection{TRIBAL RELATIONS}

Goal:

Devise a mutually acceptable means for consulting tribal governments on major project decisions.

\section{Objectives:}

Conduct meetings between staff and the Nez Perce Tribe, Confederated Tribes of the Umatilla Indian Reservation, and Yakama Indian Nation leadership.

Ensure that tribes are consulted in advance of major project decisions in accordance with DOE policy and commitments.

Provide timely information and status reports directly to the three tribal Environmental Restoration and Waste Management Offices.

Involve the DOE-RL Indian Nations Program Manager in all tribal consultation planning.

Inform the DOE-RL Cultural Resources office and consult with the tribes on all project activities that have the potential for disturbing cultural resource sites.

Coordinate activities that raise cultural awareness for SNF Project employees.

Provide facility tours and status briefings to local Indian Nations.

\subsection{COMMUNITY RELATIONS}

Goal:

Promote good will and understanding of project goals and issues among local, state, and regional business, and civic communities.

\section{Objectives:}

Provide tours, speakers bureau, management community outreach, and community partnerships.

Schedule management presentations to local and regional leaders, civic leaders, elected officials, and organizations through speaking engagements and "President's Round Table" forums. Basins.

Schedule and support limited VIP and priority stakeholder group tours of the K 
Support the Hanford Speakers Bureau with information on SNF Project issues and developments for local and regional stakeholder audiences.

\subsection{EMPLOYEE COMMUNICATIONS}

Goal:

Help create a work environment that fosters employee pride and ownership in the SNF Project mission.

\section{Objectives:}

Use employee communication tools to:

- Foster teamwork and instill in that team the importance of the project's mission for DOE, WHC, and the stakeholders.

- Recognize SNF Project employees as the "first line of defense" in protecting the Columbia River.

- Recognize SNF Project employees for successes.

- Recognize that SNF Project employees are stakeholders.

- Acknowledge that the $\mathrm{K}$ Basin workforce consistently has been given low funding priority and has not been given enough credit for working in old facilities with sub-par equipment.

- Recognize employees for working on a mission that has serious public health and safety ramifications.

- Conduct regular facility tours and status briefings for SNF Project employees.

- Conduct employee meetings to discuss employee issues. 


\subsection{COMMUNICATIONS ACTION PLAN}

Using this document as a guideline, a Communications Action Plan will be developed each Fiscal Year to define:

- Deliverables

- Cost/Estimated Resource Commitment

- Schedule

Issues

- Performance Measures 


\section{APPENDIX A}

\section{SPENT NUCLEAR FUEL PROJECT MESSAGES}

\section{Theme:}

Protect the Columbia River.

\section{Messages:}

1. How we got ourselves into this situation.

- SNF Project has received low priority and minimal funding

- the solution was always "just around the corner"

- first it was PUREX, then encapsulation

- we never looked at all the options

- until recently the public wasn't fully involved

2. Our number one priority is protecting the Columbia River.

- no discharge to the environment is acceptable

- we must isolate the fuel from the environment

- put the fuel in safe storage away from the river

3. We are taking action to solve immediate problems.

n resolved earthquake vulnerability issue

- keep the basins from leaking

fixing aging facilities/improving worker safety

4. There are many pieces to this puzzle.

- the fuel has to be analyzed before it can be moved

- can't afford to study it to death

the fuel must be retrieved, packaged, transported, stabilized and stored

- must make sure we don't trade one problem for another

- solutions must stand the test of time 
5. We're moving ahead.

- we're on a tight schedule

- we're looking at ways to move faster

- proposed approach gets the fuel away from the river fastest

- moving aggressively to protect river while long-term decisions are debated

6. Crucial decisions must be made.

- conditioning process and facility must be designed

- cost and schedule considerations

- role of private industry

- interim storage decisions must take public values into account

- $K$ Basins Environmental Impact Statement (EIS)

- DOE-HQ Programmatic EIS

- decisions require public involvement so that values, principles and perspectives are reflected 


\section{APPENDIX B}

\section{TRIBAL RELATIONS MESSAGES}

Messages:

We're forging links with tribal governments.

$\frown \quad$ It is essential that we bring tribal values to cleanup decisions.

We are strengthening Hanford's ties to tribal governments.

- We have actively sought tribal input.

- Tribal input will be invaluable in making upcoming major decisions.

- We want to make sure we clearly understand tribal government viewpoints. 
DISTRIBUTION SHEET

\begin{tabular}{|c|c|c|c|c|c|}
\hline \multirow{2}{*}{$\begin{array}{l}\text { To } \\
\text { Distribution }\end{array}$} & \multirow{2}{*}{\multicolumn{3}{|c|}{$\begin{array}{l}\text { From } \\
\text { Victor L. Hoefer }\end{array}$}} & \multicolumn{2}{|l|}{ Page 1 of 1} \\
\hline & & & & \multicolumn{2}{|c|}{ Date $12 / 11 / 95$} \\
\hline \multirow{2}{*}{\multicolumn{4}{|c|}{ Project TitleMork Order }} & \multicolumn{2}{|c|}{ EDT No. 612520} \\
\hline & & & & \multicolumn{2}{|l|}{ ECN No. } \\
\hline Name & MSIN & $\begin{array}{l}\text { Text } \\
\text { With All } \\
\text { Attach. }\end{array}$ & Text Oniy & $\begin{array}{l}\text { Attach./ } \\
\text { Appendix } \\
\text { Only }\end{array}$ & $\begin{array}{l}\text { EDT/ECN } \\
\text { Only }\end{array}$ \\
\hline $\begin{array}{l}\text { SM Braswell } \\
\text { JC Britton } \\
\text { DC Bryson } \\
\text { BS Carlisle } \\
\text { JL Denning } \\
\text { JT Eckert } \\
\text { JM Escamil10 } \\
\text { JC Fulton } \\
\text { MM Garrard } \\
\text { EW Gerber } \\
\text { CC Hages } \\
\text { RM Hiegel } \\
\text { VL Hoefer } \\
\text { SL Magnani } \\
\text { GC Mooers III } \\
\text { JW Osborne } \\
\text { GR Schroeder } \\
\text { PA Scott } \\
\text { ED Sellers } \\
\text { DE Siddoway } \\
\text { JA Swenson } \\
\text { GD Trenchard } \\
\text { MJ Wiemers } \\
\text { ME Witherspoon } \\
\text { JK Yerxa }\end{array}$ & $\begin{array}{l}\text { B3-35 } \\
\text { B3-30 } \\
S 7-41 \\
R 3-11 \\
R 3-61 \\
S 1-01 \\
S 7-41 \\
R 3-11 \\
R 3-11 \\
R 3-86 \\
R 3-11 \\
A 5-18 \\
R 3-11 \\
R 3-85 \\
R 3-11 \\
X 3-80 \\
S 7-41 \\
R 3-87 \\
S 7-41 \\
X 3-71 \\
R 3-11 \\
S 7-41 \\
X 3-85 \\
R 3-85 \\
A 7-75\end{array}$ & $\begin{array}{l}x \\
x \\
x \\
x \\
x \\
x \\
x \\
x \\
x \\
x \\
x \\
x \\
x \\
x \\
x \\
x \\
x \\
x \\
x \\
x \\
x \\
x \\
x \\
x \\
x\end{array}$ & & & \\
\hline $\begin{array}{l}\text { WHC Central Files } \\
\text { OSti }{ }_{(2)}\end{array}$ & $\begin{array}{l}A 3-88 \\
E 6-44\end{array}$ & $\begin{array}{l}x \\
x\end{array}$ & & & \\
\hline
\end{tabular}

